\title{
The Contribution of Conflict Mediation Committees on Social Harmony in Kanombe, Kicukiro district, Rwanda
}

\author{
Grace UMUHOZA $^{1}$ and Dr Ernest SAFARI ${ }^{2}$ \\ ${ }^{1}$ School of Social Sciences, Mount Kenya University, \\ Kigali, Rwanda \\ ${ }^{2}$ School of Hospitality Management, Mount Kenya University, \\ Kigali, Rwanda
}

\begin{abstract}
This study examined the contribution of conflict mediation committees on social harmony in Kanombe Sector, Rwanda. The study determined influence of collaborative approach, setting up meetings and displaying confidentiality. A descriptive and correlation research design were adopted, the sample size was 142 respondents and 16 key informants. Simple random sampling and purposive sampling techniques to administer questionnaire and interview guide. Results reveal that $55 \%$ confirmed a great extent for collaborative approach on social harmony, $52.5 \%$ strongly agree with mediation process, $60.0 \%$ were in favors of peaceful settlement. A positive correlation was exists between collaborative approach and social harmony is $0.518 * *$. Results show that $70 \%$ specified that great extent which setting up meetings, $50.0 \%$ agree that restoration of relationship was respected during mediation process and $60 \%$ agreed with attainment of community growth. A Strongly correlation was evidenced between setting up meetings and social harmony was 0.884 . Results show that $57.5 \%$ evidenced a great extent for displaying confidentiality, $60.0 \%$ strongly agree with mediation process, $55.0 \%$ agree with peaceful settlement. A positive correlation was between displaying confidentiality and social harmony is 0.874 . The study recommends double effort to raise awareness of mediation committee. Local leaders should facilitate mediation between conflicted parties.

Keywords: Conflict Mediation, Social Harmony, Peaceful Settlement, Confidentiality Restoration of Relationship, Setting up Meetings
\end{abstract}

\section{Introduction}

The growing problem consists on how restore social harmony between conflicting parties at the local level (Rahim \& Graham, 2011). In Rwandan society, domestic conflict, land conflicts hinder social harmony (Aitken, 2010). Interpersonal relationship was deteriorate due to fear, mistrust, luscious and dispute states among family members and neighbors did not effectively control. Rwanda parliament adopted a law regarding the creation of mediation committees in 2006, organic law No $31 / 2006$ of $14 / 08 / 2006$ that aimed at serving public involvement and grass roots judicial system. The mediators were assigned to mediate low level disputes within families and neighbors (MINALOC, 2018) the system allow local community members to take active role in mediating their disputes (Bukari, 2013). The contribution mediation committees on social harmony remains unclear, this could not be neglected (Upreti \& Möler, 2010). This research intends to find out the contribution of mediation committees on social harmony in the context Kanombe-Kicukiro District, Rwanda.

The research objectives were:

(i)To determine the influence of collaborative approach on social harmony in Kanombe sectorKicukiro Distrcit.

(ii)To explore the influence of setting up meetings on social harmony in Kanombe sector-Kicukiro Distrct? (iii) To ascertain the influence of displaying confidentiality on social harmony in Kanombe District-Rwanda. 


\section{Review of Literature}

A study carried out by Cheung and Ma (2010) on the role of mediation committees found out that $49.7 \%$ of disputes were resolved using transitional justice mechanisms. In this regards, each person provides input into the process, rather than have a judge make decisions. Oyeniyi(2011) asserted that this approach typically increases communication, enhances cooperation, and reduces tension. The study found out that 215 out 380 cases presented to mediation committees were resolved successful by establishing positive peace.

A study on collaborative mediation asserted that for 458 cases, only 314 used a collaborative mediation by combining the best and most successful strategies of collaborative law with the pure simplicity and cost effectiveness of mediation with outstanding success (Valters, 2013)

Astudy indicated that $19.8 \%$ of disputes were resolved using collaborative approach. Couples have the autonomy in mediation to make important decisions that fit their family and finances, rather than having a judge or arbitrator determine their fate (Vogel (2012).

In Rwanda, mediation committee's system has the advantage of being more affordable, accessible, times, participatory, restorative and has contributed to making justice more effective (Glasford \& Calgano, 2012). This study evidence that out of 4312 cases presented to mediation committees, $78.2 \%$ of cases were resolved in affordable ways.

Williams (2011) showed a significant correlation between setting up meetings and social harmony when $\mathrm{p}$ value 0.036 is less than 0.05. WOREC (2013) reiterates that out of 8312 cases presented since 10 years ago, only 5000 were able to reestablish social harmony among communities. Gurung (2013) found incompatibility between mediation and social harmony owing to the fact that less than 10.9 percent of cases only restored social harmony, others did not.

Odendaal (2013) established that with the ability to display confidentiality among disputants, near the majority, $49.8 \%$ of cases resolved using displaying confidentiality achieved a positive results in restoring social harmony. Bashyal (2011) established that with the ability to display confidentiality among disputants empowerment $38.1 \%$ of all local communities to resolve their problems to reestablish trust between them. Past studies including Wells and Kuttiparambil (2016), and (Kendie, 2010) evidenced the $78.9 \%$ of surveyed population reiterate that the prominent role of conflict mediation committees on social harmony in process of dispute resolution. General and their rights to development was taken noticeable with necessary evidence include the world conference for local and grassroots home based solution (USAID, 2012).

\section{Materials and Methods}

The study adopted a descriptive design and correlational research design where both qualitative and quantitative approaches were adopted. A sample size is defined as a subgroup representing the entire target population of the study. In this regards, the target population is 218 respondents while the sample size is obtained by using Yamane formula. In this regards, 142 sampled population was selected from 218 target population from Kanombe sector. The sample size is calculated by the following formula.

$\operatorname{Eq}(1)$ :

$n=\frac{N}{1+N(e)^{2}}$

When

$\mathrm{n}$ represent sample size; $\mathrm{N}$ represents population size; E represent margin error which is equal to 5\% (0.05)

When the Yamane formula is used in this case, the researcher obtains the sample size of 142. This technique is used by the researcher to obtain the sampled population.

$\mathrm{n}=218 / 1+218(0.05) 2$

$\mathrm{n}=218 / 1+0.545 ; \mathrm{n}=218 / 1.545 ; \mathrm{n}=218$.

A questionnaire is a group of questions for collecting data from respondents in this case were conflicting parties. Sample population had adequate time to provide necessary information. Interview was used to collected information from key informants. In this regards, key information for the present study was mediators selected in Kanombe sector proportionally with cells of the sector. In order to preserve the validity of information that was provided by respondents, theoretical knowledge work with reference and intends to establish interview guide.

\section{Results and Discussion}

\subsection{Influence of collaborative approach on social harmony}

The first objective determined the influence of collaborative approach on social harmony in Kanombe sector-Kicukiro Distrcit. This objective was achieved through the assessment of how collaborative approach was carried out, the level of 
social harmony achieved because of this approach and the correlation between collaborative approach and social harmony.

Table No.1: Correlation Analysis of the Study variables

\begin{tabular}{llll}
\hline & & Collaborative approach & $\begin{array}{l}\text { Improved } \\
\text { harmony }\end{array}$ \\
\hline Collaborative approach & Pearson Correlation & 1 & $.518^{* *}$ \\
& Sig.(2-tailed) & & .000 \\
& $\mathrm{~N}$ & 142 & 142 \\
Improved social harmony & Pearson Correlation & $.518^{* *}$ & 1 \\
& Sig.(2-tailed) & .000 & 142 \\
\hline
\end{tabular}

*Correlation is significant at the 0.005 level (2-tailed).

Results indicates that learning how to leave with other people group have $4.02, \mathrm{~S}=0.933$ standard deviation. It was however noted that the mean for responses for high initiative to improve social harmony had the lowest mean and highest Std. Deviation $(=3.81, \mathrm{~S}=1.129)$. It was however noted that the mean extended from 3.9 to 4.02 which was very close. The Std. deviation also fluctuated from 0.933 to 1.129 . Further, information indicated that the coefficient relationship between collaborative approach and social harmony is $0.518^{* *}$. It implied the significant relationship between collaborative approach and the improved social harmony whereby had contributed to the restoration of social harmony among local communities. It means that participatory approach (learning how to leave with other people group, being flexible and tolerate minor errors, respecting personal thoughts and choice and foster understanding and respect, Seeking equitable and fair agreement) influences social harmony.

\subsection{The influence of setting up meetings on social harmony in Kanombe sector}

The second objective analyzed the influence of setting meetings on social harmony in Kanombe sector Kicukiro Distrcit. Results revealed that strong setting up meetings among conflicting parties as low standard deviation. Therefore, $X=4.25, \mathrm{~S}=0.733$ showing low level of change and high level of agreement. It was noted that mean for responses for information gathering was the lowest mean and highest Std. Deviation $(X=4.01, \mathrm{~S}=1.033)$. The standard deviation for those who agreed was more (5.21) than the other responses implying greater variability in responses.

Table No.2 Correlation Analysis of the Study Variables

\begin{tabular}{llll}
\hline & & $\begin{array}{l}\text { Setting } \\
\text { up meetings }\end{array}$ & $\begin{array}{c}\text { Improve } \\
\text { Harmony }\end{array}$ \\
\hline Setting up Meetings & Pearson Correlation & 1 & $.884^{* *}$ \\
& Sig.(2-tailed) & & .000 \\
& $\mathrm{~N}$ & 142 & 142 \\
Improved social harmony & $.884 * *$ & 1 \\
& Pearson Correlation & .000 & 142 \\
\hline
\end{tabular}

*Correlation is significant at the 0.05 level (2-tailed).

Therefore, information indicated that coefficient relation between setting up meetings and social harmony in Kanombe Sector was 0.884. The evidences implied a positive correlation between setting up meetings and social harmony of local communities in Kanombe Sector of Kicukiro Distrcit, whereby had contributed significantly to the restoration of social harmony. This implies a positive correlation between setting up meetings and social harmony

\begin{abstract}
4.3.The influence of displaying confidentiality on social harmony in Kanombe district-Rwanda The third objective established the influence of displaying confidentiality on social harmony in Kanombe District-Rwanda. Results vindicated the information collected on displaying confidentiality among conflicting parties and demonstrated a standard deviation of $4.37, \mathrm{~S}=0.780$ ) reflecting a high change and a remarkable agreement. It was noted that mean for responses for citizens are effectively and openly communicate towards dispute resolution $=3.52, \mathrm{~S}=0.995$.
\end{abstract}


Table No3: Correlation Analysis of the Study variables

\begin{tabular}{llll}
\hline & & $\begin{array}{l}\text { Displaying } \\
\text { confidentiality }\end{array}$ & $\begin{array}{l}\text { Improved } \\
\text { harmony }\end{array}$ \\
\hline Displaying confidentiality & Pearson & 1 & $.874^{* *}$ \\
& Correlation & 1 & .000 \\
Improved social harmony & Si.(2-tailed) & & 142 \\
& $\mathrm{~N}$ & 142 & 1 \\
& Pearson & $.874 * *$ & \\
& Correlation & .000 & 142 \\
\hline
\end{tabular}

*Correlation is significant at the 0.05 level (2-tailed).

Source: Primary data (2020)

Findings indicated that coefficient correlation between displaying confidentiality and the restoration of social harmony is 0.874 . It means that there is a significant correlation between displaying confidentiality and improved social harmony in Kanombe sector hence has contributed to the development of company.

\section{Discussion}

Results to the first object agree with Cheung and Ma (2010) who argued that participation playing different participatory roles in promoting social harmony in the respective literature. This agrees with Onslow (2010) who argued that participatory approach most often helps in promoting social harmony and community cohesion. As Oyeniyi (2011) notes, the best execution begins with an adequate strategic sources and that the soup is only as ingredients. Authors like Ross (2010) for example, established that the procedures of participatory approach and social harmony among conflicting parties and team stimulate a greater social cohesion and harmony. This is helpful for peacebuilding and conflict resolution (Stein, 2013).

Results to the second objective reveled respondent's agreement on setting up meetings among conflicting parties introductory meetings, problem statement, information gathering, identification of the problems and bargaining (Suurmond, \& Sharma, 2012). This agrees with Tamata (2012) argued that communities in which workers have accessibility to information from managers were due to public and helpful information. This agrees with Stein and Valters (2012) who noted that setting up meetings refers to any other element that encourage the restoration of interpersonal relationship. He further said that setting up meetings comprises of explanation of new assignments, tasks and responsibilities necessary for social cohesion. These results are consistent with Vogel (2012) study which revealed that whether citizens of an organization did not have similar information passing through several layers in a local community, a low level of agreement. This did not have enough understanding which can be a challenge to interpersonal relationship. However, copying strategies were adopted by mediation committees.

Results to the first objective, agree with Wall, Wu, \& Beriker (2010) who argued that displaying confidentiality. Humanitarian intervention is a prominent concern for local, national and global community. However, women did not have awareness on how to make decisions, inaccessibility to resources for rebuilding procedures (Carter Center,2010).Therefore, it was very crucial to enable them to survive in the post conflict period in order to accumulate all gains relate to empowerment achieved.

However, women did not have awareness on how to make decisions, inaccessibility to resources for rebuilding procedures (Carter Center,2010). The subjective approach believed that conflict was the result of the perception of the parties. The objective approach stated that a conflict existed whenever there is incompatible interests or goals regardless of whether or not the parties are aware of these differences (WOREC, 2013). This agrees with WOREC (2013) who argued that displaying confidentiality within a mediation committees .

\section{Conclusions}

Results presented reveal that $55 \%$ confirmed a great extent for collaborative approach on social harmony, $52.5 \%$ strongly agree that restoration of relationship was attained after mediation process, $60.0 \%$ were in favors of a great extent for the achievement of peaceful settlement. A positive correlation was exists between collaborative approach and social harmony is $0.518 * *$. Results from the second objective show that $70 \%$ specified that great extent which setting up 
meetings, $50.0 \%$ agree that restoration of relationship was respected during mediation process and $60 \%$ agreed on the attainment of community growth. A Strongly correlation was evidenced between setting up meetings and social harmony was 0.884. Results of the third objectives show that $57.5 \%$ evidenced a great extent for displaying confidentiality by mediation committees, $60.0 \%$ strongly agree that restoration of relationship was respected after mediation process, $55.0 \%$ agree on peaceful settlement. A positive correlation was reflected between displaying confidentiality and restoration of social harmony is 0.874 . The study recommends double effort to raise awareness of mediation committee. Local leaders should play a key role in facilitating mediation between conflicted

\section{Reference}

[1] Aitken, K. M. (2010). Justice should be blind, but is the international community's support to informal justice mechanisms in Nepal given blindly. Nepal.

[2] Ansari, M. (2013). Agents of Change, Member of Nepal's Women's Commission. Feature article, International Institute for Democracy and Electoral Assistance.

[3] Bashyal, R.P. (2011). Domestic Violence Act and its implication on society. New Spotlight $\begin{array}{lllll}\text { News } & \text { Magazine. } & 6 & 5 & \text { (6). }\end{array}$ http://www.spotlightnepal.com/News/Article.

[4] Beardsley, K. (2010). Pain, Pressure, and Political Cover: Explaining Mediation Incidence." Journal of Peace Research. Forthcoming.

[5] Bucyensenge, J.P. (2014). Rwanda: community mediators' role in solving conflicts hailed, allAfrica.com

[6] Bukari, K.N. (2013). The peace process in the Bawku conflict: Prospects and Challenges. Conflict \& Communication online, Vol.12

[7] Carter Center. (2010). Brief Overview of Political Dispute Resolution at the Local Level in Nepal.http://www.cartercenter.org/resources/pdfs/ne ws/peace_publications/election_reports/nepalPolitica 1DisputeResOverview-123010_en.pdf.Retrieved on Access $15^{\text {th }}$ September 2019

[8] Chaudhary, D. (2011). An Anthropological Study. Empowering Women through Microfinance'. Available at:

http://www.microcreditsummit.org/papers/empower ment.pdf.Retrived from on 12th March 2020.

[9] Cheung, C., and Ma, S. K. (2010). Coupling Social Solidarity and Social Harmony in Hong Kong. Social Indicators Research, 103(1), pp.145-167. 34

[10] Glasford, D. and Calgano, J. (2012). 'The conflict of harmony: Intergroup contact, commonality and political solidarity between parties. Non-governmental organizations (NGOs) and regional organizations generally should extent their activities to reach all population in need because they have to respond to a number of cases and issues at the same time, each of which may vary considerably.

\section{Acknowledgments}

I wish to acknowledge Dr. Ernest SAFARI for her contribution to this work from the beginning up to it's the completion. I also wish to extend my acknowledgement to the Mount Kenya University, Kicukiro authorities for their support and collaborative in term of data collection.

minority groups'. Journal of Experimental Social Psychology, 48(1), pp.323-328.

[11] Gurung, P.1. (2013). Home is not a safe place for women: Gender-based violence and its situation in Nepal. Journa of Republica, 20 September. Page 5.

[12] Kendie, S. B. (2010). Conflict management and peace building for poverty reduction. Tamale: GILLBT Press.

[13] Kothari, R. (2012). Methods and Teaching in Research Methodology 17(2) (pp. 152-271). New Delhi: New Age Publishers.

[14] Odendaal, A. (2013). The usefulness of national mediation in intra-state conflict in Africa, Centre for mediation in Africa. University of Pretoria [15] Odendaal. A. (2010). An architecture for building peace at the local level: A comparative study of local peace committees. A Discussion Paper: Commissioned by the Bureau for Crisis Prevention and Recovery of the United Nations Development Program, Washington DC, USA.

[16] Onslow, C. (2010). Country Case Study: Nepal. Breaking Patterns of Sexual and GenderBased Violence: Security and Justice Provision in Post-Conflict Nepal. International Alert. London. UK.

[17] Oyeniyi, A. (2011). Conflict and violence in Africa: Causes, sources and types. Journal of Transcend Media Service. 23(6), pp.1002-1034

[18] Ross, M.H. (2010). Creating the conditions for peacemaking: theories of practice in ethnic conflict resolution. Ethnic and Racial Studies 23(6), pp.1002-1034.

[19] Stein, D. (2013). Community mediation and social harmony in Nepal. JSRP Paper 5 Theories in Practice Series. Justice and Security Research Program, TAF. 23(6), pp.1002-1034

[20] Stein, D. and Valters, C. (2012). Theory of Change in International Development: A Review of Existing Knowledge, London: UK. 
[21] Suurmond, J. \& Sharma, P.M. (2012). Like yeast that leavens the dough? Community mediation as local infrastructure for peace in Nepal. Journal of Peacebuilding \& Development 7(3): 81-86.

[22] Tamata, T. (2012). Promoting Access to Justice through Alternative Dispute Resolution in Nepal: Support for community and court-annexed mediation. http://a2jportal.org/nepal Justice and Courts. Retrieved from 23 April 2020.

[23] USAID. (2012). Building resilience to recurrent crisis: USAID policy and program guidance.

http://www.usaid.gov/sites/default/files/documents. Retrieved from $26^{\text {th }}$ March 2020

[24] Valters, C. (2013). Community Mediation and Social Harmony in Sri Lanka', JSRP Paper 4 Theories in Practice series. Journal of Justice and
ISSN 2455-6378

Security Research Program and The Asia Foundation. 23(6), pp.1002-1034

[25] Vogel, I. (2012). Review of the use of 'Theory of Change' in international development. London: DFID

[26] Wall, J. A., Wu, S., \& Beriker, N. (2010). Turkish Community Mediation. Journal of Applied Social Psychology, 40(8), pp.2019-2042.

[27] Williams, M. (2011) Workplace conflict management: awareness and use of Acas code of practice and workplace meditation - A poll of business, Acas Research Paper, 08/11.

[28] WOREC. (2013). Violence against women: overview of violence against women in Nepal. http://www.worecnepal.org/programs/violenceagainst-women.Retrieved from 22 December 2019 